\title{
BMJ
}

\section{Mortality in British military participants in human experimental research into chemical warfare agents at Porton Down: cohort study}

\begin{abstract}
K M Venables, reader in occupational medicine, ${ }^{1}$ C Brooks, data manager , ${ }^{1} \mathrm{~L}$ Linsell, medical statistician, T J Keegan, research fellow, ${ }^{1} \mathrm{~T}$ Langdon, assistant data manager, ${ }^{1} \mathrm{~T}$ Fletcher, senior lecturer in environmental epidemiology, ${ }^{2}$ M J Nieuwenhuiijsen, research professor in environmental epidemiology, ${ }^{3}$ visiting professor, ${ }^{4} \mathrm{~N}$ E S Maconochie, senior lecturer in epidemiology and medical statistics, ${ }^{5}$ P Doyle, professor of epidemiology, ${ }^{5} \mathrm{~V}$ Beral, professor and director, ${ }^{6} \mathrm{~L}$ M Carpenter, reader in statistical epidemiology ${ }^{1}$
\end{abstract}

Department of Public Health University of Oxford, Oxford OX3 7LF

${ }^{2}$ Department of Public Health and Policy, London School of Hygiene and Tropical Medicine, London

${ }^{3}$ Centre for Research in

Environmental Epidemiology, IMIM and CIBERESP, 08003

Barcelona, Spain

${ }^{4}$ Division of Epidemiology, Public Health and Primary Care, Imperial College, London

${ }^{5}$ Department of Epidemiology and Population Health, London Schoo of Hygiene and Tropical Medicine London

${ }^{6}$ Cancer Epidemiology Unit, University of Oxford, Oxford Correspondence to: $\mathrm{K} M$ Venables kate.venables@dphpc.ox.ac.uk; L M Carpenter

lucy.carpenter@dphpc.ox.ac.uk

Cite this as: $B M J$ 2009;338:b613 doi:10.1136/bmj.b613 gramme" in which, since 1916, at least 30000 people,

\section{ABSTRACT}

Objective To investigate any long term effects on mortality in participants in experimental research related to chemical warfare agents from 1941 to 1989.

Design Historical cohort study.

Data sources Archive of UK government research facility at Porton Down, UK military personnel records, and national death and cancer records.

Participants 18276 male members of the UK armed forces who had spent one or more short periods (median 4 days between first and last test) at Porton Down and a comparison group of 17600 non-Porton Down veterans followed to 31 December 2004.

Main outcome measures Mortality rate ratio of Porton Down compared with non-Porton Down veterans and standardised mortality ratio of each veteran group compared with the general population. Both ratios adjusted for age group and calendar period.

Results Porton Down veterans were similar to non-Porton Down veterans in year of enlistment (median 1951) but had longer military service (median $6.2 v 5.0$ years). After a median follow-up of 43 years, $40 \%$ (7306) of Porton Down and $39 \%$ (6900) of non-Porton Down veterans had died. All cause mortality was slightly greater in Porton Down veterans (rate ratio $1.06,95 \%$ confidence interval 1.03 to $1.10, \mathrm{P}<0.001)$, more so for deaths outside the UK (1.26, 1.09 to 1.46$)$. Of 12 cause specific groups examined, rate ratios in Porton Down veterans were increased for deaths attributed to infectious and parasitic $(1.57,1.07$ to 2.29$)$, genitourinary $(1.46,1.04$ to 2.04$)$, circulatory $(1.07,1.01$ to 1.12$)$, and external (non-medical) $(1.17,1.00$ to 1.37$)$ causes and decreased for deaths attributed to in situ, benign, and unspecified neoplasms $(0.60,0.37$ to 0.99$)$. There was no clear relation between type of chemical exposure and cause specific mortality. The mortality in both groups of veterans was lower than that in the general population (standardised mortality ratio $0.88,0.85$ to $0.90 ; 0.82,0.80$ to 0.84 ).

Conclusions Mortality was slightly higher in Porton Down than non-Porton Down veterans. With lack of information on other important factors, such as smoking or service overseas, it is not possible to attribute the small excess mortality to chemical exposures at Porton Down.

\section{INTRODUCTION}

After the use of chemical warfare agents in the first world war, the UK government initiated research at Porton Down to study their potential impact on military capability and the effectiveness of protective measures. ${ }^{1-5}$ This included a "human volunteer promainly servicemen are thought to have taken part. ${ }^{3}$ After ex-servicemen expressed concern about whether participation might have damaged their health in the long term, the UK government commissioned this epidemiological study in 2002. There have been few studies of participants in such human experimental programmes $^{6-9}$ and results from mortality studies in American servicemen have been inconclusive. ${ }^{7-10} \mathrm{~A}$ recent survey of members of a UK veterans' support group found them to report poorer quality of life than the general population. ${ }^{11}$ This is the first report of mortality and cancer morbidity ${ }^{12}$ in the cohort of British participants in the chemical tests at Porton Down.

\section{METHODS}

Assembly of the Porton Down veteran cohort

Our pilot study found that service number, essential for retrieving military personnel files, was routinely recorded at Porton Down only from 1 April 1941. Our cohort comprised all members of the UK armed forces recorded as having participated in the "human volunteer programme" from 1 April 1941 to 31 December 1989. We initially identified potential cohort members using a database of 20006 names previously abstracted by a team employed by the Ministry of Defence from documents in the historical archive at Porton Down. This was compared against 
$\overline{\text { Table 1| Characteristics of } 18276 \text { Porton Down veterans and } 17600 \text { non-Porton Down veterans. }}$ Figures are numbers (percentages) of veterans

\begin{tabular}{|c|c|c|}
\hline Characteristic & Porton Down veterans & Non-Porton Down veterans \\
\hline \multicolumn{3}{|l|}{ Service at enlistment: } \\
\hline Army & $11407(62.4)$ & $10872(61.8)$ \\
\hline Air force & $4026(22.0)$ & $3987(22.7)$ \\
\hline Navy (and marines) & $2843(15.6)$ & $2741(15.6)$ \\
\hline \multicolumn{3}{|l|}{ Decade of birth: } \\
\hline Before 1920 & $3742(20.5)$ & $3794(21.6)$ \\
\hline $1920 \mathrm{~s}$ & $3515(19.2)$ & $3211(18.2)$ \\
\hline $1930 \mathrm{~s}$ & $6088(33.3)$ & $5977(34.0)$ \\
\hline 1940 s or later & $4931(27.0)$ & $4618(26.2)$ \\
\hline \multicolumn{3}{|l|}{ Place of birth: } \\
\hline England & $14295(79.2)$ & $13761(78.9)$ \\
\hline Wales & $931(5.2)$ & $919(5.3)$ \\
\hline Scotland & $1785(9.9)$ & $1803(10.3)$ \\
\hline Northern Ireland & $307(1.7)$ & $248(1.4)$ \\
\hline Republic of Ireland & 265 (1.5) & $261(1.5)$ \\
\hline Overseas & $458(2.5)$ & $444(2.5)$ \\
\hline Missing & 235 & 164 \\
\hline \multicolumn{3}{|l|}{ Age (years) at enlistment: } \\
\hline$\ll 16$ & $1237(6.8)$ & $1220(6.9)$ \\
\hline $16-\ll 18$ & $4987(27.4)$ & $4290(24.4)$ \\
\hline $18-\prec 20$ & $6495(35.7)$ & $6211(35.3)$ \\
\hline $20-<22$ & $2270(12.5)$ & $2354(13.4)$ \\
\hline$\geq 22$ & $3226(17.7)$ & $3517(20.0)$ \\
\hline Missing & 61 & 8 \\
\hline \multicolumn{3}{|l|}{ Period at enlistment*: } \\
\hline Before second world war & $975(5.4)$ & $884(5.0)$ \\
\hline During second world war & $5275(29.0)$ & $5048(28.7)$ \\
\hline After second world war & $7814(42.9)$ & $7667(43.6)$ \\
\hline After national service & $4151(22.8)$ & $3993(22.7)$ \\
\hline Missing & 61 & 8 \\
\hline \multicolumn{3}{|l|}{ Rank at enlistment: } \\
\hline Private (or equivalent) & $18094(99.3)$ & $17438(99.4)$ \\
\hline Other & $122(0.7)$ & $112(0.6)$ \\
\hline Missing & 60 & 50 \\
\hline \multicolumn{3}{|c|}{ Duration of service at first visit to Porton Down (years): } \\
\hline$<2$ & $8160(44.8)$ & NA \\
\hline $2-\ll 3$ & $3087(17.0)$ & NA \\
\hline $3-<5$ & $3572(19.6)$ & NA \\
\hline $5-<10$ & $2341(12.9)$ & NA \\
\hline$\geq 10$ & $1055(5.8)$ & NA \\
\hline Missing & 61 & \\
\hline \multicolumn{3}{|c|}{ Total duration of service (years)†: } \\
\hline$<2$ & $438(2.4)$ & $2771(15.8)$ \\
\hline $2-\ll 3$ & $2830(15.6)$ & $3406(19.4)$ \\
\hline $3-\ll 5$ & $2823(15.6)$ & $2728(15.5)$ \\
\hline $5-\ll 10$ & $7011(38.6)$ & $5565(31.6)$ \\
\hline$\geq 10$ & $5043(27.8)$ & $3117(17.7)$ \\
\hline Missing & 131 & 13 \\
\hline \multicolumn{3}{|c|}{ Vital status at 31 December 2004: } \\
\hline Alive & $10409(57.0)$ & $10222(58.1)$ \\
\hline Deceased & $7306(40.0)$ & $6900(39.2)$ \\
\hline \multicolumn{3}{|l|}{ Follow-up censored at: } \\
\hline Discharge from services & $438(2.4)$ & $346(2.0)$ \\
\hline Emigration & $68(0.4)$ & $69(0.4)$ \\
\hline Other & $55(0.3)$ & $63(0.4)$ \\
\hline
\end{tabular}

NA=not applicable.

*Second world war dates taken as 1 September 1939 to 30 April 1945; national service dates taken as 1 May 1945 to 31 December 1960.

†Includes 148 Porton Down veterans, and 132 non-Porton Down veterans still serving at time of data abstraction. the names identified during our abstraction of exposure data.

Names and service numbers were submitted to the relevant military personnel records authority: army, air force, navy, and marines. We excluded civilian staff $(\mathrm{n}=344)$ and members of non-UK armed forces $(\mathrm{n}=220)$. Personnel files were successfully retrieved for 18441 Porton Down veterans, and identifiers necessary for data linkage were manually abstracted and entered with a standard format onto a secure computer. For army veterans, this was carried out by a team of six people employed by the University of Oxford and based at the army personnel archive. For army personnel still in active service, and for air force, navy, and marine veterans, Ministry of Defence employees trained by the research team abstracted data. The research team directed quality control procedures at all sites.

Where possible, data on service number, name, sex, date and place of birth, mother's maiden name, NHS number, national registration identity number, national insurance number, dates of recruitment and discharge (with corresponding addresses, service numbers, and ranks), and date of death were abstracted. Names of veterans whose personnel files could not be located after identification details were checked and after a second attempt at file retrieval were submitted to the Ministry of Defence for circulation to relevant central departments. All data abstracted from personnel files were returned to the university and checked for data abstraction or entry errors. Any data discrepancies later identified were corrected, when appropriate.

\section{Assembly of the comparison cohort}

We identified a comparison group of veterans who did not visit Porton Down ("non-Porton Down veterans"). Our pilot study showed that a sample of veterans with adjacent service numbers to Porton Down veterans had similar distributions of important characteristics, such as date of birth. So, within each branch of the military, we generated a service number adjacent to (above or below) that of each Porton Down veteran and retrieved the corresponding personnel file for data abstraction and entry in the same way as for the Porton Down veterans. If a file was not found, the alternative adjacent service number was submitted and, if necessary, the process repeated. Personnel files were successfully retrieved for 18103 non-Porton Down veterans and over $95 \%$ had service numbers immediately adjacent to the corresponding Porton Down veteran.

\section{Follow-up}

The primary source of mortality data in the UK is the National Health Service central register (NHSCR). We submitted the required identification details to the register in Southport, which traced deaths, and, when available, emigrations, for England and Wales, and managed personnel data submission for tracing to the registers in Scotland and Northern Ireland. Untraced veterans were checked against the website of the 
Commonwealth War Graves Commission (CWGC), a registry of deaths in Commonwealth service personnel occurring in the two world wars between 1914 and 1947 (www.cwgc.org). Names not traced by NHSCR and not found on the commission's website were submitted to the Department for Work and Pensions (DWP) for classification as dead, alive, or vital status not known. For veterans identified by the DWP as having died, we obtained copies of death certificates, when available, from NHSCR.

Each condition on the death certificate, including the underlying cause, was coded by the Office for National Statistics according to ICD-10 (international classification of diseases, 10th revision). Death certificates were not available for deaths not registered in the UK, so cause of death was unknown.

\section{Exposures of Porton Down veterans}

To assess exposure we used contemporaneous experimental records in the Porton Down historical archive following a protocol reported elsewhere. ${ }^{1314}$ In brief, data abstraction involved linking, when possible, each test to an individual veteran and the classification of that test as involving a chemical or not. Each chemical test was classified as involving vesicant(s), nerve agent (s), or other chemical(s). For vesicants (blistering agents) and nerve agents, detailed information relating to exposure was abstracted. ${ }^{14}$ For analyses reported here, we grouped Porton Down veterans as ever or never exposed at least once to any chemical, any vesicant, any nerve agent, or any other chemical, and to specific chemicals to which at least 1000 veterans had been exposed. "High" exposure subgroups were defined as elsewhere. ${ }^{14}$

\section{Mortality analysis}

We decided on the classifications of exposures and causes of death before we linked the exposure and outcome databases. Analyses reported relate to underlying cause of death in 18276 male Porton Down veterans and 17600 male non-Porton Down veterans, excluding women (134 and 127 respectively) and men with missing data (31 and 376 respectively). All

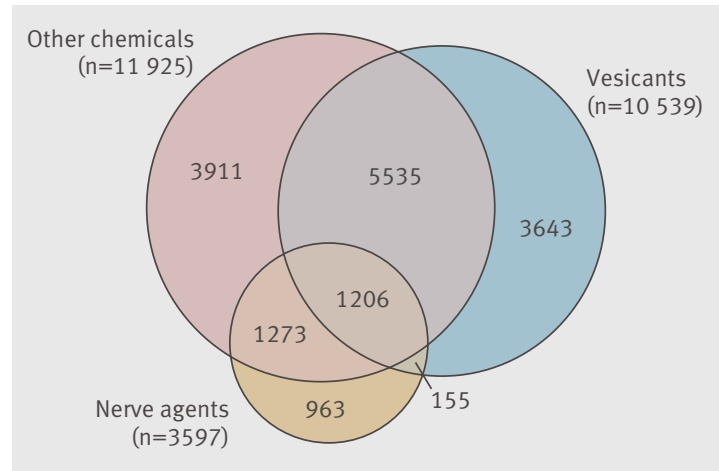

Fig 1| Overlap of exposure groups in 16686 Porton Down veterans (excludes 1590 not recorded as exposed to any chemical)
Table 2 |Summary of exposures in 18276 Porton Down veterans, 1941-89

\begin{tabular}{|c|c|}
\hline & No (\%) of veterans \\
\hline \multicolumn{2}{|l|}{ No of tests: } \\
\hline 1 & $2173(11.9)$ \\
\hline $2-5$ & $4161(22.8)$ \\
\hline $6-9$ & 3814 (20.9) \\
\hline $10-14$ & $3080(16.9)$ \\
\hline$\geq 15$ & $4075(22.3)$ \\
\hline None & $973(5.3)$ \\
\hline \multicolumn{2}{|l|}{ Decade of first test*: } \\
\hline $1940 \mathrm{~s}$ & $6504(35.6)$ \\
\hline $1950 \mathrm{~s}$ & $6097(33.4)$ \\
\hline $1960 \mathrm{~s}$ & $2260(12.4)$ \\
\hline $1970 \mathrm{~s}$ & $1966(10.8)$ \\
\hline $1980 \mathrm{~s}$ & $1449(7.9)$ \\
\hline \multicolumn{2}{|l|}{ No of chemical testst: } \\
\hline$\geq 1$ & $16686(91.3)$ \\
\hline None & $1590(8.7)$ \\
\hline \multicolumn{2}{|l|}{ Type of chemical test $†$ : } \\
\hline \multicolumn{2}{|l|}{ Vesicant: } \\
\hline Any & $10539(57.7)$ \\
\hline Sulphur mustard $\ddagger$ & $10273(56.2)$ \\
\hline Lewisite & $1745(9.5)$ \\
\hline Nitrogen mustard & $1183(6.5)$ \\
\hline \multicolumn{2}{|l|}{ Nerve agent: } \\
\hline Any & 3597 (19.7) \\
\hline Sarin & $2980(16.3)$ \\
\hline \multicolumn{2}{|l|}{ Other chemical: } \\
\hline Any & $11925(65.2)$ \\
\hline CS & $1328(7.3)$ \\
\hline$C R$ & $1175(6.4)$ \\
\hline Pralidoxime & $1696(9.3)$ \\
\hline Atropine & $1577(8.6)$ \\
\hline
\end{tabular}

*Date of first visit for those with no test data.

tIncludes 17303 veterans for whom type of test could be determined. łlncludes mustard sensitivity tests.

analyses used STATA version 8.2 (www.stata.com). Significance was defined as $\mathrm{P}<0.05$ with two sided tests.

Comparison with national mortality rates - Person years of follow-up for Porton Down veterans started from the earliest date (after 1 April 1941) they were recorded as included in a test at Porton Down; for the 973 for whom a test date was not available, we counted person years from the date of arrival at Porton Down as recorded in the Ministry of Defence database. Person years for nonPorton Down veterans started from a date derived by adding to the enlistment date the interval between the dates of the corresponding Porton Down veteran's enlistment and first visit to Porton Down. For the 65 non-Porton Down veterans for whom we did not know date of enlistment, we counted person years from the same date as for the corresponding Porton Down veteran. Person years stopped at the earliest of date of death, loss to follow-up, or 31 December 2004. For losses to follow-up, we censored person years at the last known date alive in the UK (such as date of emigration or date of discharge from the services). We stratified person years and deaths according to 15 five year age 
Table $3 \mid$ All cause mortality in Porton Down veterans and non-Porton Down veterans compared with national mortality rates according to service at enlistment. Standardised mortality ratios ( $95 \%$ confidence intervals) adjusted for calendar year and age group

\begin{tabular}{|c|c|c|c|c|}
\hline & \multicolumn{2}{|c|}{ Porton Down veterans } & \multicolumn{2}{|c|}{ Non-Porton Down veterans } \\
\hline & Observed deaths* & Standardised mortality ratio & Observed deaths* & Standardised mortality ratio \\
\hline All veterans & 6885 & $0.88(0.85$ to 0.90$)$ & 6582 & $0.82(0.80$ to 0.84$)$ \\
\hline \multicolumn{5}{|l|}{ Service at enlistment: } \\
\hline Army & 5100 & 0.88 (0.86 to 0.91$)$ & 4892 & 0.84 (0.81 to 0.86$)$ \\
\hline Air force & 965 & $0.77(0.72$ to 0.82$)$ & 929 & 0.72 (0.68 to 0.77$)$ \\
\hline Navy (and marines) & 820 & 0.97 (0.90 to 1.03$)$ & 761 & 0.88 (0.81 to 0.94$)$ \\
\hline
\end{tabular}

groups $(15-19,20-24$, etc, to $\geq 85)$ and by single calendar year (from 1941 to 2004). We calculated expected deaths by multiplying the person years for each five year age group and single calendar year by the corresponding national rates for England, Wales, and Scotland and estimated standardised mortality ratios

All deaths
UK deaths
Overseas deaths
UK deaths by cause group
Infectious and parasitic
Malignant neoplasms
In situ, benign, and unspecified neoplasm
Endocrine, nutritional, and metabolic
Mental and behavioural
Nervous system
Circulatory system
Respiratory system
Digestive system
Musculoskeletal system
Genitourinary system
External causes

\section{Any}

No of deaths

54441.06 (1.02 to 1.10$)$ 50991.05 (1.01 to 1.09) 3451.25 (1.07 to 1.46$)$

$49 \quad 1.41$ (0.94 to 2.12 )

15031.02 (0.95 to 1.09 )

150.47 (0.26 to 0.87$)$

481.01 (0.69 to 1.48 )

421.05 (0.71 to 1.58$)$

850.93 (0.71 to 1.22$)$

22801.06 (1.00 to 1.12$)$

5581.05 (0.94 to 1.18 )

1481.06 (0.86 to 1.32 )

190.89 (0.49 to 1.62$)$

651.44 (1.01 to 2.06$)$

2111.23 (1.02 to 1.48 )

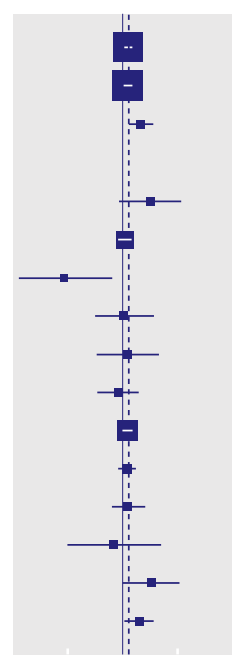

Any Lewisite

$\begin{array}{lccc}\text { All deaths } & 1395 & 1.16(1.09 \text { to } 1.23) \\ \text { UK deaths } & 1291 & 1.15(1.08 \text { to } 1.22) \\ \text { Overseas deaths } & 104 & 1.28(1.01 \text { to } 1.61) \\ \text { UK deaths by cause group } & & & \\ \text { Infectious and parasitic } & 16 & 1.85(0.95 \text { to } 3.46) \\ \text { Malignant neoplasms } & 356 & 1.07(0.95 \text { to } 1.20) \\ \text { In situ, benign, and unspecified neoplasms } & 7 & 0.97(0.36 \text { to } 2.26) \\ \text { Endocrine, nutritional, and metabolic } & 14 & 1.41(0.71 \text { to } 2.64) \\ \text { Mental and behavioural } & 11 & 1.07(0.50 \text { to } 2.13) \\ \text { Nervous system } & 25 & 1.27(0.81 \text { to } 1.99) \\ \text { Circulatory system } & 598 & 1.16(1.06 \text { to } 1.27) \\ \text { Respiratory system } & 158 & 1.18(0.99 \text { to } 1.41) \\ \text { Digestive system } & 33 & 1.17(0.80 \text { to } 1.73) \\ \text { Musculoskeletal system } & 7 & 1.46(0.52 \text { to } 3.58) \\ \text { Genitourinary system } & 17 & 1.53(0.82 \text { to } 2.73) \\ \text { External causes } & 32 & 1.18(0.80 \text { to } 1.74)\end{array}$

Any sulphur mustard

No of Rate ratio deaths $(95 \% \mathrm{CI})$

52991.06 (1.02 to 1.10)

49601.05 (1.01 to 1.09 )

3391.27 (1.08 to 1.48 )

$48 \quad 1.42$ (0.94 to 2.14)

14641.02 (0.95 to 1.09)

$140.46(0.25$ to 0.85$)$

461.00 (0.68 to 1.46$)$

411.06 (0.70 to 1.58$)$

820.92 (0.70 to 1.21$)$

22161.06 (1.00 to 1.12 )

5431.05 (0.93 to 1.18$)$

1441.06 (0.86 to 1.32 )

190.91 (0.50 to 1.66$)$

631.43 (1.00 to 2.05 )

2071.24 (1.03 to 1.49 )

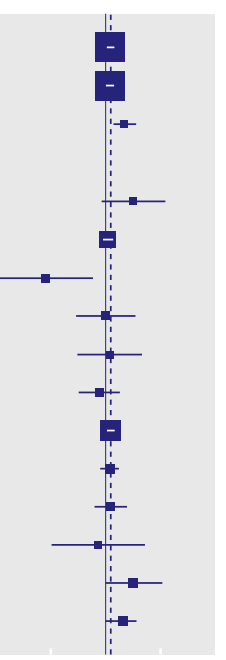

Any nitrogen mustard

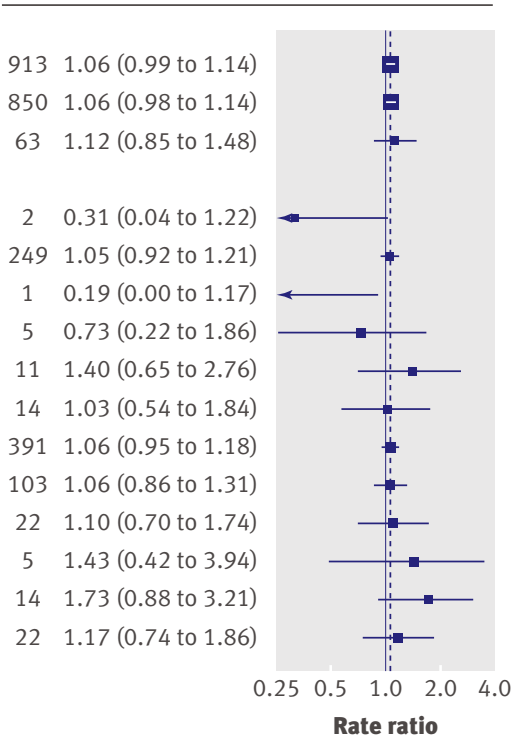


Table $4 \mid$ Cause specific mortality in Porton Down veterans compared with non-Porton Down veterans. Rate ratios $(95 \%$ confidence intervals) with and without adjustment for age group and calendar period

\begin{tabular}{|c|c|c|c|c|}
\hline & \multicolumn{2}{|c|}{ Observed deaths } & \multicolumn{2}{|c|}{ Rate ratio } \\
\hline & $\begin{array}{l}\text { Porton Down } \\
\text { veterans }\end{array}$ & $\begin{array}{c}\text { Non-Porton Down } \\
\text { veterans }\end{array}$ & Unadjusted & $\begin{array}{l}\text { Adjusted } \\
(95 \% \mathrm{Cl})\end{array}$ \\
\hline \multicolumn{5}{|l|}{ All causes (ICD-10 code) } \\
\hline Total & 7306 & 6900 & 1.03 & $1.06^{\star \star \star}(1.03$ to 1.10$)$ \\
\hline All deaths registered in UK (A00-Z99) & 6885 & 6582 & 1.02 & $1.06^{\star \star}(1.02$ to 1.09$)$ \\
\hline All deaths not registered in UK & 421 & 318 & $1.29^{\star \star \star}$ & $1.26^{\star *}(1.09$ to 1.46$)$ \\
\hline \multicolumn{5}{|l|}{ Cause specific mortality in UK (ICD-10 code) } \\
\hline Infectious and parasitic (A00-B99) & 66 & 43 & 1.49 & $1.57^{\star}(1.07$ to 2.29$)$ \\
\hline \multicolumn{5}{|l|}{ Malignant neoplasms: } \\
\hline All (C00-97) & 2093 & 2041 & 1.00 & 1.03 (0.97 to 1.10$)$ \\
\hline Upper aerodigestive (C00-14, C30-32) & 59 & 57 & 1.01 & 1.03 (0.71 to 1.48$)$ \\
\hline Oesophagus (C15) & 86 & 99 & 0.85 & $0.87(0.65$ to 1.16$)$ \\
\hline Stomach (C16) & 152 & 137 & 1.08 & 1.13 (0.89 to 1.42$)$ \\
\hline Intestine and rectum (C17-20) & 198 & 188 & 1.02 & $1.06(0.87$ to 1.30$)$ \\
\hline Pancreas (C25) & 83 & 89 & 0.91 & $0.94(0.70$ to 1.27$)$ \\
\hline Trachea, bronchus, and lung $(\mathrm{C} 33, \mathrm{C} 34)$ & 785 & 726 & 1.05 & 1.09 (0.98 to 1.21$)$ \\
\hline Melanoma and other skin $(\mathrm{C} 43, \mathrm{C} 44)$ & 26 & 31 & 0.82 & 0.83 (0.49 to 1.40$)$ \\
\hline Prostate (C61) & 146 & 149 & 0.95 & $1.01(0.80$ to 1.27$)$ \\
\hline Urinary tract (C64-68) & 122 & 126 & 0.94 & $0.98(0.76$ to 1.26$)$ \\
\hline Brain and other central nervous system $(C 71, C 72)$ & 46 & 58 & 0.77 & $0.78(0.53$ to 1.15$)$ \\
\hline All lymphatic and haematopoietic (C81-96) & 128 & 132 & 0.94 & 0.96 (0.76 to 1.23$)$ \\
\hline All other malignant neoplasms $†$ & 262 & 249 & 1.02 & $1.06(0.89$ to 1.26$)$ \\
\hline In situ, benign, and unspecified neoplasms (D10-48) & 25 & 42 & $0.58^{\star}$ & $0.60^{\star}(0.37$ to 0.99$)$ \\
\hline Endocrine, nutritional, and metabolic (E00-90) & 65 & 70 & 0.90 & 0.94 (0.67 to 1.31$)$ \\
\hline Mental and behavioural (F00-99) & 53 & 51 & 1.01 & $1.08(0.73$ to 1.59$)$ \\
\hline Nervous system (G00-99) & 104 & 132 & 0.77 & $0.80(0.62$ to 1.03$)$ \\
\hline \multicolumn{5}{|l|}{ Circulatory system: } \\
\hline All (100-99) & 3007 & 2851 & 1.03 & $1.07^{\star}(1.01$ to 1.12$)$ \\
\hline Ischaemic heart diseases (120-25) & 2021 & 1884 & 1.04 & $1.08^{\star}(1.01$ to 1.15$)$ \\
\hline Cerebrovascular diseases (160-69) & 504 & 501 & 0.98 & 1.03 (0.91 to 1.17$)$ \\
\hline All other circulatory $(100-19,126-59,170-99)$ & 482 & 466 & 1.01 & $1.05(0.93$ to 1.20$)$ \\
\hline \multicolumn{5}{|l|}{ Respiratory system: } \\
\hline All (000-99) & 694 & 662 & 1.02 & 1.07 (0.96 to 1.19$)$ \\
\hline Chronic lower respiratory tract (J40-47) & 426 & 417 & 0.99 & 1.04 (0.91 to 1.19$)$ \\
\hline All other respiratory (100-39, J48-99) & 268 & 245 & 1.06 & 1.12 (0.94 to 1.33$)$ \\
\hline Digestive system (K00-93) & 218 & 206 & 1.03 & 1.05 (0.87 to 1.27$)$ \\
\hline Musculoskeletal system and connective tissue (M00-99) & 23 & 27 & 0.83 & $0.87(0.50$ to 1.51$)$ \\
\hline Genitourinary system (N00-99) & 81 & 57 & 1.38 & $1.46^{*}(1.04$ to 2.04$)$ \\
\hline All external causes (S00-T98, V01-Y98) & 341 & 284 & 1.17 & $1.17^{\star}(1.00$ to 1.37$)$ \\
\hline All other UK deaths with ICD code & 44 & 39 & 1.10 & 1.12 (0.73 to 1.73$)$ \\
\hline All other UK deaths with no ICD code & 71 & 77 & 0.90 & $0.92(0.67$ to 1.27$)$ \\
\hline
\end{tabular}

†C21-24, C26-29, C37-41, C45-50, C60, C62, C63, C69, C70, C73-80, C97.

†D50-89, H00-95, L00-99, Q00-99, R00-99, U00-89, Z00-99.

${ }^{\star} \mathrm{P}<0.05 ;{ }^{\star *} \mathrm{P}<0.01 ;{ }^{\star * *} \mathrm{P}<0.001$.

from the ratio of observed to expected deaths. We obtained 95\% confidence intervals and tests of significance using the normal approximation to the Poisson distribution.

Comparison of mortality between Porton Down and nonPorton Down veterans - Person years were calculated as above except that we did not censor losses to follow-up at the last known date alive in the UK. We estimated adjusted rate ratios and 95\% confidence intervals and derived $\mathrm{P}$ values by the Mantel-Haenszel method with deaths and person years stratified according to five year age groups (as above) and five year calendar periods
(1941-4, 1945-9, etc, to 2000-4). ${ }^{15}$ When the number of expected deaths in either group of veterans was less than 10, we estimated adjusted rate ratios and tested for significance by fitting exact conditional Poisson regression models to the stratified data. ${ }^{16}$ Following the approach to exposure outlined above, we compared mortality rates in specific exposure groups of Porton Down veterans with that of all non-Porton Down veterans. For groups of causes where there was either a prior hypothesis of association, or the data suggested an association, we calculated rate ratios for subgroups with "high" exposure. ${ }^{14}$ 
Table $5 \mid$ All cause mortality in Porton Down veterans compared with non-Porton Down veterans according to time since first test. Rate ratios adjusted for five year age group and five year calendar period

\begin{tabular}{|c|c|c|c|c|c|c|}
\hline \multirow{2}{*}{$\begin{array}{l}\text { Years since first } \\
\text { test }\end{array}$} & \multicolumn{2}{|r|}{ All deaths } & \multicolumn{2}{|c|}{ Deaths registered in UK } & \multicolumn{2}{|c|}{ Deaths not registered in UK } \\
\hline & Deaths & Rate ratio $(95 \% \mathrm{Cl})$ & Deaths & Rate ratio $(95 \% \mathrm{Cl})$ & Deaths & Rate ratio $(95 \% \mathrm{Cl})$ \\
\hline$<2$ & 170 & 1.14 (0.91 to 1.42$)$ & 34 & 1.11 (0.68 to 1.83$)$ & 136 & 1.14 (0.89 to 1.47$)$ \\
\hline $2-<5$ & 144 & $1.29^{\star}(1.01$ to 1.66$)$ & 39 & 0.91 (0.59 to 1.40$)$ & 105 & $1.53^{\star \star}(1.13$ to 2.09$)$ \\
\hline $5-\ll 10$ & 74 & 1.04 (0.76 to 1.43$)$ & 68 & $1.01(0.73$ to 1.41$)$ & 6 & $1.54(0.44$ to 5.40$)$ \\
\hline $10-<20$ & 282 & 1.04 (0.88 to 1.22$)$ & 270 & 1.03 (0.87 to 1.23$)$ & 12 & 1.08 (0.48 to 2.42$)$ \\
\hline $20-<40$ & 2579 & $1.07^{\star \star}(1.02$ to 1.13$)$ & 2535 & $1.07^{\star \star}(1.01$ to 1.13$)$ & 44 & $1.20(0.77$ to 1.87$)$ \\
\hline$\geq 40$ & 4057 & $1.05^{\star \star}(1.01$ to 1.10$)$ & 3939 & $1.05^{\star \star}(1.00$ to 1.10$)$ & 118 & $1.28(0.97$ to 1.68$)$ \\
\hline Total & 7306 & $1.06^{\star \star \star}$ (1.03 to 1.10$)$ & 6885 & $1.06^{\star \star}(1.02$ to 1.09$)$ & 421 & $1.26^{\star \star}(1.09$ to 1.46$)$ \\
\hline
\end{tabular}

${ }^{*} \mathrm{P}<0.05,{ }^{* * \mathrm{P}<0.01,{ }^{*} * * \mathrm{P}<0.001}$

\section{RESULTS}

Of the Porton Down veterans, 62\% (11407/18 276) had joined the army, 22\% (4026) the air force, and 16\% (2843) the navy, including the marines. As expected, the distribution of service at enlistment of the 17600 non-Porton Down veterans was virtually identical (table 1). Most veterans were born in England before 1940 and joined the British armed services as teenagers during periods of conscription, either in the second world war (1939-45) or in the period of compulsory male military service ("national service") after the war to 1960 (table 1). The median year of enlistment was 1951 for both groups. Almost all had enlisted with the rank of private (or equivalent). Over half of Porton Down veterans had been in military service for less than three years when they first went to Porton Down. Of the military and demographic factors examined in this study, the only clear difference between the two cohorts was that Porton Down veterans had a longer duration of military service. Fewer Porton Down than non-Porton Down veterans stayed for less than two years $(2 \%(438 / 18145) v 16 \%(2771 / 17587))$ and more stayed for 10 or more years (28\% (5043) v 18\% (3117)) (table 1). The median duration of military service was 6 . 2 years (interquartile range 4.2-11.4) for Porton Down veterans and $5.0(2.1-7.5)$ for non-Porton Down veterans.

The median interval between first and last test carried out at Porton Down was four days (interquartile range 1-8 days), and median number of days on which tests were performed was two (1-4). ${ }^{14}$ For 69\% (12 601/ 18276) of the Porton Down veterans, the first recorded visit to Porton Down was in the 1940 s or 1950 s (table 2). The type of test could be determined for 95\% (17 303) of veterans and, of these, $91 \%$ (16 686) were in at least one test involving a chemical. Fifty eight per cent of veterans (10 539) were in at least one test involving a vesicant, 20\% (3597) a nerve agent, and 65\% (11925)

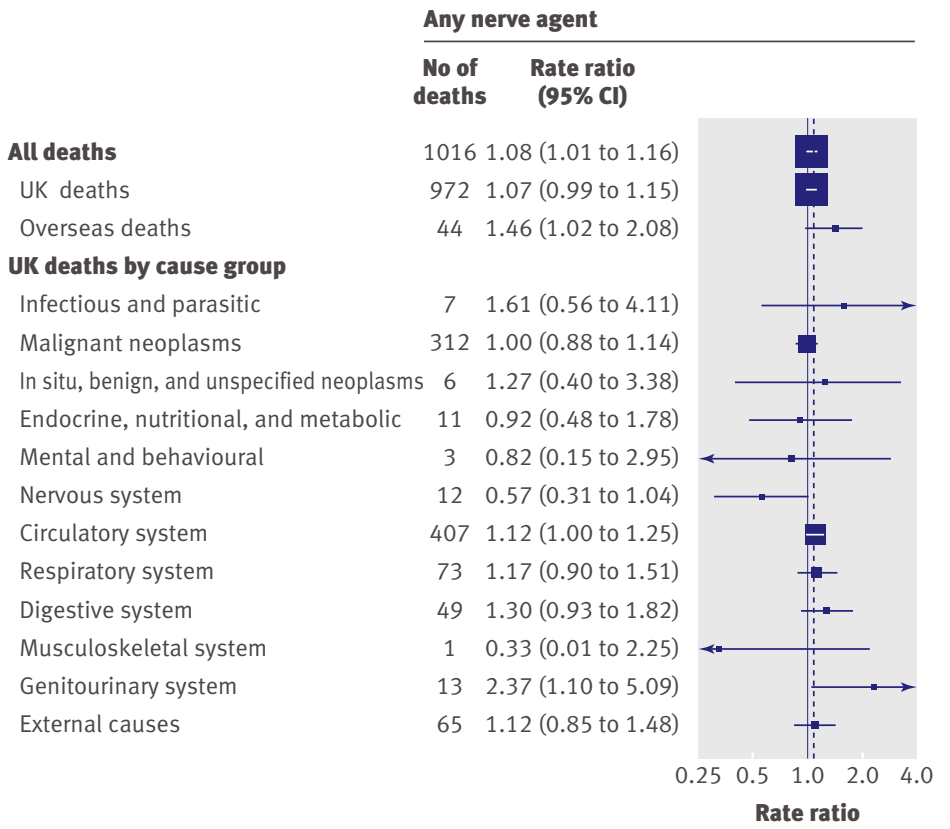

\begin{tabular}{lc} 
Any sarin \\
\hline $\begin{array}{c}\text { No of } \\
\text { deaths }\end{array}$ & $\begin{array}{c}\text { Rate ratio } \\
(95 \% \mathrm{Cl})\end{array}$
\end{tabular}

8001.09 (1.01 to 1.18$)$

7661.08 (1.00 to 1.17$)$

341.44 (0.97 to 2.14$)$

51.54 (0.43 to 4.49$)$

2461.01 (0.88 to 1.17$)$

$4 \quad 1.12(0.27$ to 3.51$)$

$10 \quad 1.07$ (0.54 to 2.13 )

$31.13(0.20$ to 4.21$)$

$90.53(0.26$ to 1.07$)$

3221.15 (1.02 to 1.30$)$

481.03 (0.75 to 1.40$)$

391.30 (0.90 to 1.88$)$

$0 \quad 0.00$ (0.00 to 2.00)

92.04 (0.81 to 4.76)

611.26 (0.94 to 1.68$)$

$\begin{array}{lllll}0.25 & 0.5 & 1.0 & 2.0 & 4.0\end{array}$

Rate ratio

Fig 3 | Rate ratios for cause specific mortality in Porton Down veterans included in test(s) involving nerve agent(s) compared with non-Porton Down veterans, adjusted for age and calendar period. Rate ratio estimates are represented by box with size inversely proportional to variance. Vertical dotted line shows estimate for all deaths. For clarity, only rows for major ICD chapter headings are presented 
Table 6 | Mortality by selected underlying causes (ICD-10 code) for Porton Down veterans with high recorded levels of exposure to specific chemicals, relative to non-Porton Down veterans. Rate ratios adjusted for age group and calendar period $(95 \% \mathrm{Cl})$

\begin{tabular}{|c|c|c|}
\hline Chemical and indicator of high exposure & No of deaths & Adjusted rate ratio $(95 \% \mathrm{Cl})$ \\
\hline \multicolumn{3}{|l|}{ Sulphur mustard } \\
\hline \multicolumn{3}{|l|}{ Dermal $\geq 10.63 \mathrm{mg}:$} \\
\hline Upper aerodigestive cancers (C00-C14, C30-C32) & 10 & $0.76(0.34$ to 1.51$)$ \\
\hline Cancers of trachea, bronchus, and lung $(\mathrm{C} 33, \mathrm{C} 34)$ & 195 & $0.99(0.84$ to 1.16$)$ \\
\hline Diseases of circulatory system (100-199) & 804 & 1.04 (0.96 to 1.12$)$ \\
\hline Chronic lower respiratory tract diseases (140-J47) & 118 & 0.99 (0.81 to 2.07$)$ \\
\hline All external causes (S00-T98, V01-Y98) & 69 & $1.22(0.93$ to 1.60$)$ \\
\hline \multicolumn{3}{|l|}{ Dermal vesicle: } \\
\hline Upper aerodigestive cancers (C00-C14, C30-C32) & 17 & 1.19 (0.68 to 2.07$)$ \\
\hline Cancers of trachea, bronchus, and lung $(\mathrm{C} 33, \mathrm{C} 34)$ & 259 & $1.12(0.92$ to 1.29$)$ \\
\hline Diseases of circulatory system (100-199) & 1004 & $1.11^{\star \star}(1.01$ to 1.12$)$ \\
\hline Chronic lower respiratory tract diseases (140-J47) & 162 & $1.13(0.94$ to 1.36$)$ \\
\hline All external causes (S00-T98, V01-Y98) & 80 & $1.35^{*}(1.01$ to 1.75$)$ \\
\hline \multicolumn{3}{|l|}{ Lewisite } \\
\hline \multicolumn{3}{|l|}{ Dermal $\geq 13.69$ mg: } \\
\hline Cancers of trachea, bronchus, and lung $(\mathrm{C} 33, \mathrm{C} 34)$ & 27 & $1.10(0.75$ to 1.61$)$ \\
\hline Melanoma and other skin cancers (C43, C44) & 1 & $1.86(0.04$ to 12.83$)$ \\
\hline Diseases of circulatory system (100-199) & 109 & 1.14 (0.94 to 1.38$)$ \\
\hline \multicolumn{3}{|l|}{ Dermal vesicle: } \\
\hline Cancers of trachea, bronchus, and lung $(\mathrm{C} 33, \mathrm{C} 34)$ & 73 & $1.25(0.98$ to 1.60$)$ \\
\hline Melanoma and other skin cancers (C43, C44) & 0 & 0.00 (0.00 to 3.13$)$ \\
\hline Diseases of circulatory system (100-199) & 261 & $1.14^{*}(1.01$ to 1.30$)$ \\
\hline \multicolumn{3}{|l|}{ Nitrogen mustard } \\
\hline \multicolumn{3}{|l|}{ Dermal $\geq 23.73 \mathrm{mg}:$} \\
\hline Melanoma and other skin cancers (C43, C44) & 2 & $3.50(0.37$ to 16.21$)$ \\
\hline All lymphatic and haematopoetic (C81-C96) & 3 & 0.83 (0.17 to 2.53$)$ \\
\hline \multicolumn{3}{|l|}{ Dermal vesicle: } \\
\hline Melanoma and other skin cancers (C43, C44) & 1 & $1.65(0.04$ to 11.42$)$ \\
\hline All lymphatic and haematopoetic (C81-C96) & 1 & $0.26(0.01$ to 1.52$)$ \\
\hline \multicolumn{3}{|l|}{ Sarin } \\
\hline \multicolumn{3}{|l|}{ Air $\geq 14.99 \mathrm{mg} \cdot \mathrm{min} / \mathrm{m}^{3}:$} \\
\hline Diseases of circulatory system (100-199) & 61 & 1.22 (0.94 to 1.58$)$ \\
\hline \multicolumn{3}{|l|}{ Cholinesterase fall $\geq 30 \%$ : } \\
\hline Diseases of circulatory system (100-199) & 99 & $1.18(0.96$ to 1.45$)$ \\
\hline \multicolumn{3}{|l|}{ Atropine (two or more tests) } \\
\hline Diseases of genitourinary system (N00-N99) & 2 & $5.83(0.64$ to 25.00$)$ \\
\hline
\end{tabular}

another chemical group (neither vesicant nor nerve agent) (table 2), with considerable overlap (fig 1). There were eight specific chemicals for which there were records of at least 1000 Porton Down veterans having been tested: three vesicants (sulphur mustard, Lewisite, and nitrogen mustard), one nerve agent (sarin), two lachrymators (CS and CR), and two anti-nerve agent pharmaceutical chemicals (pralidoxime and atropine) (table 2). The median number of tests per veteran was five for vesicants, one for nerve agents, and three for other chemicals. ${ }^{14}$

After a median follow-up of over 40 years (median 43.2 (interquartile range 31.4-51.0) for Porton Down and 43.7 (31.9-51.1) for non-Porton Down veterans), $40 \%(\mathrm{n}=7306)$ of Porton Down and 39\% (6900) of nonPorton Down veterans were notified as dead (table 1). All cause mortality in both groups was less than in the general population, with variation by branch of the services (table 3).
All cause mortality in the Porton Down veterans was higher than that of the comparison group (rate ratio $1.06,95 \%$ confidence interval 1.03 to 1.10 , table 4 ), particularly in deaths not registered in the UK $(1.26$, 1.09 to 1.46$)$. For UK deaths, we compared mortality in 12 groups of underlying causes (table 4). In four groups, there was a significant excess: infectious and parasitic (1.57, 1.07 to 2.29$)$, genitourinary $(1.46,1.04$ to 2.04$)$, circulatory $(1.07,1.01$ to 1.12 ), and external (nonmedical) $(1.17,1.00$ to 1.37$)$ causes. There was a significant deficit for in situ, benign, and unspecified neoplasms (0.60, 0.37 to 0.99 ).

When we restricted analysis to veterans with two or more years of service, the all cause mortality rate ratio was similar (1.07, 1.03 to 1.10). Rate ratios for all cause mortality were also examined by time since first test (table 5). The overall excess mortality relative to nonPorton Down veterans seemed to be present at all stages of follow-up examined.

Figures 2, 3, and 4 present rate ratios according to chemical exposure group. The excess all cause mortality seen in the whole cohort was seen in most groups, as were several of the associations with cause specific mortality. Lewisite exposure was associated with cancers of the trachea, bronchus, and lung (1.19, 1.00 to 1.43). Table 6 presents rate ratios for selected causes of death in subgroups with "high" exposure; in none was the estimate higher than the upper bound of the $95 \%$ confidence interval for the rate ratio for the exposure group as a whole.

\section{DISCUSSION}

Mortality in men in the armed forces who took part in tests at Porton Down from 1941-89 was slightly higher than that of similar veterans who did not take part (rate ratio 1.06). This excess was particularly evident in deaths from infectious and parasitic, circulatory, genitourinary, and external (non-medical) causes, as well as in deaths overseas for which no underlying cause was available. The excess in overseas deaths might be related to the longer duration of military service in the Porton Down veterans as they might have had more overseas military postings. Mortality from cancer was not increased, a similar finding to that for cancer morbidity. ${ }^{12}$ At the same time, overall mortality in Porton Down veterans was 12\% lower than that of the general population. This is perhaps not surprising because these men had all met the selection criteria for military service; similarly low mortality has been found in other UK military cohorts, such as nuclear test veterans and submariners. ${ }^{1718}$

\section{Strengths and weaknesses}

Our cohort is the largest reported to date with experimental exposure to chemical warfare agents and related chemicals and includes over 17000 exposed veterans compared with 6720 and 1545 veterans studied in the United States. ${ }^{7-10}$ As well as collecting detailed exposure information ${ }^{1314}$ we assembled a comparison group of similar veterans who did not attend Porton Down. The median duration 
of follow-up was over 40 years and should be sufficient for major long term risks to emerge.

\section{Previous research}

One possible explanation for the excess mortality is the chemical exposures received by the veterans or other aspects of the experience of visiting Porton Down. The best previous evidence for long term effects on health of chemical warfare agents relates to the vesicant sulphur mustard. Increased mortality from respiratory cancer was noted in US casualties from sulphur mustard in the first world war ${ }^{1920}$ and in UK disability pensioners from the first world war who had been affected by sulphur mustard. ${ }^{21}$ UK workers who manufactured sulphur mustard in the second world war had raised mortality from malignant and non-malignant respiratory disease ${ }^{22}$ and there were similar findings from Japan. ${ }^{23}$ Iranian authors associated sulphur mustard exposure in the Iran-Iraq war (1980-8) with respiratory disorders. ${ }^{24}$ There was no evidence of these effects in US navy veterans exposed experimentally to sulphur mustard. ${ }^{10}$ In Porton Down veterans with exposure to sulphur mustard, there was an $8 \%$ excess mortality from respiratory cancers and a $2 \%$ excess from nonmalignant respiratory diseases, but these were not statistically significant and the findings in the "high" exposure subgroups were inconsistent. The probable explanation is that, whereas manufacturing workers accumulated months or years of exposure in repeated shifts, servicemen spent only days or weeks in these experimental programmes and the number of instances of exposure was fewer. Furthermore, in

$\begin{array}{lcc} & \begin{array}{c}\text { Any other chemical } \\$\cline { 2 - 3 }\end{array} \\ $\begin{array}{l}\text { No of } \\ \text { deaths }\end{array} & \begin{array}{c}\text { Rate ratio } \\ (\mathbf{9 5 \%} \mathbf{C l})\end{array} \\ \begin{array}{l}\text { All deaths } \\ \text { UK deaths }\end{array} & 3856 & 1.06(1.02 \text { to } 1.10) \\ \text { Overseas deaths } & 222 & 1.21(1.01 \text { to } 1.09) \\ \text { UK deaths by cause group } & 37 & 1.58(1.02 \text { to } 2.45) \\ \text { Infectious and parasitic } & 1165 & 1.02(0.95 \text { to } 1.09) \\ \text { Malignant neoplasms } & 13 & 0.56(0.30 \text { to } 1.06) \\ \text { In situ, benign, and unspecified neoplasm }) \\ \text { Endocrine, nutritional, and metabolic } & 39 & 0.99(0.67 \text { to } 1.47) \\ \text { Mental and behavioural } & 33 & 1.19(0.76 \text { to } 1.87) \\ \text { Nervous system } & 63 & 0.85(0.63 \text { to } 1.15) \\ \text { Circulatory system } & 1662 & 1.06(1.00 \text { to } 1.13) \\ \text { Respiratory system } & 368 & 1.06(0.93 \text { to } 1.20) \\ \text { Digestive system } & 135 & 1.09(0.88 \text { to } 1.36) \\ \text { Musculoskeletal system } & 12 & 0.84(0.43 \text { to } 1.63) \\ \text { Genitourinary system } & 45 & 1.48(1.00 \text { to } 2.19) \\ \text { External causes } & 214 & 1.12(0.94 \text { to } 1.34) \\ & & \end{array}$

\section{All deaths}

UK deaths

Overseas deaths

\section{UK deaths by cause group}

Infectious and parasitic

Malignant neoplasms

In situ, benign, and unspecified neoplasms Endocrine, nutritional, and metabolic Mental and behavioural

Nervous system

Circulatory system

Respiratory system

Digestive system

Musculoskeletal system

Genitourinary system

External causes

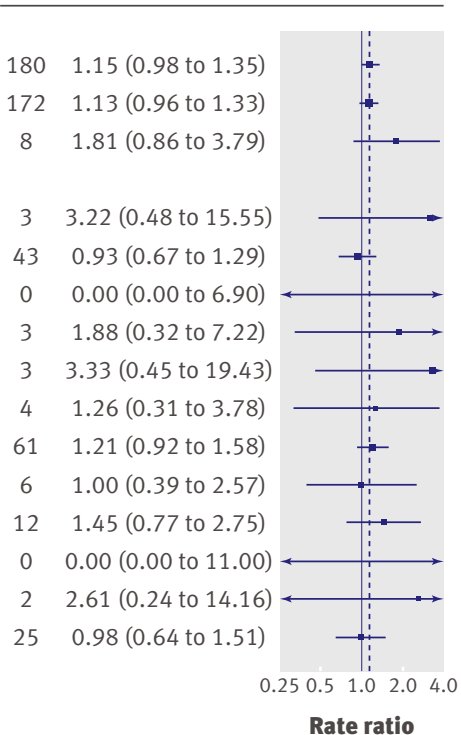

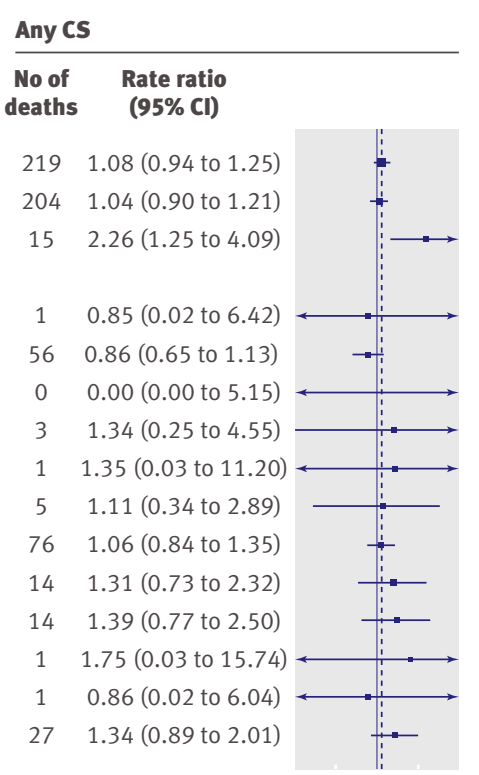

Any atropine

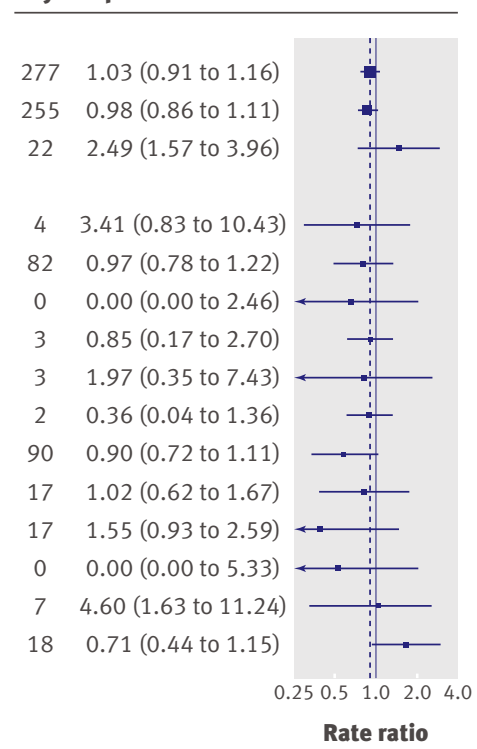

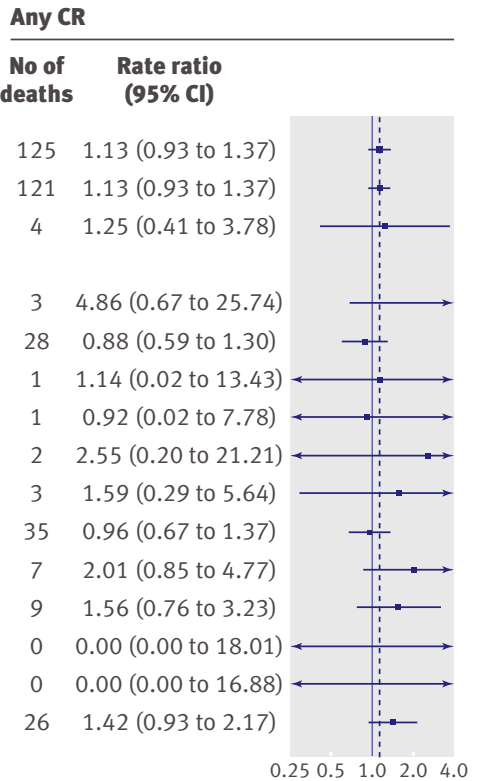

Rate ratio

Fig 4 | Rate ratios for cause-specific mortality in Porton Down veterans included in test(s) involving any other chemical(s) compared with non-Porton Down veterans, adjusted for age and calendar period. Rate ratio estimates are represented by box with size inversely proportional to variance. Vertical dotted line shows estimate for all deaths. For clarity, only rows for major ICD chapter headings are presented 


\section{WHAT IS ALREADY KNOWN ON THIS TOPIC}

Since the first world war, research programmes into chemical warfare agents and defences against them have involved experiments on members of the armed forces

Few studies have looked at the long term effects on their health

\section{WHAT THIS STUDY ADDS}

Mortality was slightly higher than expected in UK veterans of the programme at Porton Down

It was not possible to attribute the higher mortality to these chemicals in the absence of data on other risk factors, such as smoking

many of the tests the veterans wore protective equipment, which would have reduced their uptake of sulphur mustard. ${ }^{14}$

There have been few previous studies on the long term effects of these chemicals other than sulphur mustard.$^{6-9}$ Although nitrogen mustard has been associated with leukaemias, ${ }^{25}$ mortality from lymphatic and haematopoietic cancers was not increased in this study. Our findings suggest that Lewisite exposure in Porton Down veterans might be associated with mortality from cancers of the trachea, bronchus, and lung. ${ }^{12}$

\section{Interpretation}

The associations we found between chemical exposure group and cause specific mortality are difficult to interpret. While they might represent effects of exposure at Porton Down, it is also possible that Porton Down and non-Porton Down veterans differed in ways that relate to mortality, leading to confounding. For example, the longer total military service of Porton Down veterans might imply differences in military factors such as overseas postings. We did not collect information about lifestyle factors that affect mortality, of which the most important is smoking. This limits interpretation, particularly of the excess of deaths attributed to circulatory causes, which are associated with smoking. Although the longer duration of military service in Porton Down veterans might indicate health related survival, the all cause mortality rate ratio was unchanged when we restricted analysis to those with two or more years of service.

The large number of outcomes and exposures means that some significant associations might have occurred by chance. On the other hand, we might have missed some genuine risks. Another potential limitation of this study, shared by all analyses of underlying cause of death, is that it is most informative about diseases with poor survival.

\section{Summary}

This large cohort study with detailed information on chemical exposure provides insights into the long term health of Porton Down veterans. Mortality was slightly higher than in non-Porton Down veterans but with the lack of information about other important factors, such as smoking or service overseas, we cannot attribute a small excess such as this to chemical exposures at Porton Down.

We thank the research team who worked on the study (Monica Smith, Marita Lowry, Alison Howell, Margaret Chandler, Owen Rogers, the late Janice Hurwood, Sue Walker, Chris Shield, Nicola Pata, Kate Brockhurst, Steve Davies, lan Palmer, and Madeleine Harwood); staff from the Ministry of Defence (MoD) who abstracted personnel data for the study; and Bianca De Stavola, David Cox, and Michael Hills for input on analytical methods. We also thank the following organisations for their contributions to different aspects of the study: Medical Research Council (MRC) Porton Down Research Liaison Group, Porton Down Veterans Support Group, MoD Veterans Policy Unit, Defence Science and Technology Laboratory at Porton Down, National Health Service Central Register, General Register Office for Scotland, Office for National Statistics, and Department for Work and Pensions. Figure 1 was originally generated with an applet developed by Peter Rodgers, University of Kent, and Stirling Chow, University of Victoria, Canada: www.cs.kent.ac.uk/people/staff/pjr/EulerVennCircles/ EulerVennApplet.html. Figures 2-4 were originally plotted by Adrian Goodill, Cancer Epidemiology Unit, University of Oxford.

Contributors: KMV and LMC jointly led the study and are guarantors. All authors participated in the study design, plan of analysis, interpretation of the results, and drafting of the paper. LL carried out the statistical analyses.

Funding: This study was funded by the MRC with funds provided to it by the MoD. Additional funds were provided by the Department of Public Health and Nuffield College, University of Oxford. The MRC set up a liaison group to oversee the progress of the study. The MoD had no role in study design, analysis, and interpretation of data. The MoD facilitated access to its archives but had no role in deciding which data were abstracted. The MoD was sent a copy of the paper for factual comment but had no role in writing the paper or in the decision to submit for publication. The universities of Oxford and London are independent of both the MRC and the MoD.

Competing interests: None declared

Ethical approval: The study was approved by the south east multicentre research ethics committee, the Defence Medical Services clinical research committee, and the Patient Information Advisory Group.

1 Harris R, Paxman J. A higher form of killing. London: Chatto and Windus, 1982.

2 Carter GB. Chemical and biological defence at Porton Down, 19162000. London: Stationery Office, 2000.

3 Evans R. Gassed. London: House of Stratus, 2000.

4 Coleman K. A history of chemical warfare. Basingstoke: Palgrave, 2005.

5 Ministry of Defence. Historical survey of the Porton Down service volunteer programme 1939-1989. London: Ministry of Defence, 2006. www.mod.uk

6 Committee to survey the health effects of mustard gas and Lewisite. Pechura CM, Rall DP, eds. Veterans at risk: the health effects of mustard gas and Lewisite. Washington, DC: National Academy Press, 1993.

7 National Research Council. Possible long term effects of short term exposure to chemical agents. Vol 1. Anticholinesterases and anticholinergics. Washington DC: National Academy Press, 1982.

8 National Research Council. Possible long term effects of short term exposure to chemical agents. Vol 2. Cholinesterase reactivators, psychochemicals, and irritants and vesicants. Washington DC: National Academy Press, 1984.

9 National Research Council. Possible long term effects of short term exposure to chemical agents. Vol 3. Final report: health status of test subjects. Washington, DC: National Academy Press, 1985.

10 Bullman T, Kang H. A fifty year mortality follow-up study of veterans exposed to low level chemical warfare agent, mustard gas. Ann Epidemiol 2000;10:333-8.

11 Allender S, Maconochie N, Keegan T, Brooks C, Fletcher T, Nieuwenhuijsen MJ, et al. Symptoms, ill-health and quality of life in Porton Down veterans. Occup Med 2006;56:329-37.

12 Carpenter LM, Linsell L, Brooks C, Keegan TJ, Langdon T, Doyle P, et al. Cancer morbidity in British military participants in chemical warfare agent experiments at Porton Down: cohort study. BMJ 2009;b655.

13 Keegan TJ, Nieuwenhuijsen MJ, Fletcher T, Brooks C, Doyle P, Maconochie NES, et al. Reconstructing exposures from the UK chemical warfare agent human research programme. Ann Occup Hyg 2007;51:441-50.

14 Keegan TJ, Walker SAS, Brooks C, Langdon T, Linsell L, Maconochie NES, et al. Exposures recorded for participants in the UK chemical warfare agent human research programme, 1941-1989. Ann Occup Hyg 2009;53:83-97. 
15 Mantel N, Haenszel W. Statistical aspects of the analysis of data from retrospective studies of disease. J Natl Cancer Inst 1959;22:719-48.

16 Clayton D, Hills M. Statistical models in epidemiology. Oxford: Oxford University Press, 1993.

17 Darby SC, Muirhead CR, Doll R, Kendall GM, Thakrar B. Mortality among United Kingdom servicemen who served abroad in the 1950s and 1960s. BrJ Ind Med 1990;47:793-804.

18 Inskip HS, Snee M, Styles, L. The mortality of Royal Naval submariners 1960-89. Occup Environ Med 1997;54:209-15.

19 Beebe G. Lung cancer in World War 1 veterans: possible relation to mustard gas injury and 1918 influenza epidemic. J Natl Cancer Inst 1960;25:1231-52.

20 Norman JE Jr. Lung cancer mortality in World War I veterans with mustard-gas injury: 1919-1965. J Natl Cancer Inst 1975;54:311-7.

21 Case RAM, Lea AJ. Mustard gas poisoning, chronic bronchitis and lung cancer. An investigation into the possibility that poisoning by mustard gas in the 1914-18 war might be a factor in the production of neoplasia. BrJ Prev Soc Med 1955;9:62-72.

22 Easton DF, Peto J, Doll R. Cancers of the respiratory tract in mustard gas workers. Br J Ind Med 1988;45:652-9.

23 Wada S, Miyanishi M, Nishimoto Y, Kambe S, Miller RW. Mustard gas as a cause of respiratory neoplasia in man. Lancet 1968;i:1161-3.

24 Balali-Mood M, Hefazi M, Mahmoudi M, Jalali E, Attaran D, Maleki M, et al. Long-term complications of sulphur mustard poisoning in severely intoxicated Iranian veterans. Fundam Clin Pharmacol 2005;19:713-21.

25 International Agency for Research on Cancer. IARC monographs on the evaluation of carcinogenic risks to humans. Lyon: IARC. http:// monographs.iarc.fr/.

Accepted: 5 December 2008 